\title{
Effect of Retting of African Breadfruit Pulp on the Oil Characteristics of the Seeds
}

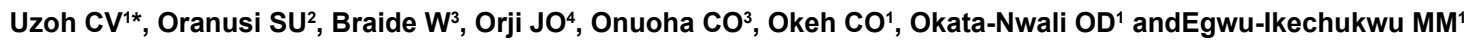 \\ ${ }^{1}$ Department of Microbiology,Federal University Ndufu-Alike Ikwo, PMB 1010 Abakaliki, Ebonyi State, Nigeria \\ ${ }^{2}$ Department of Biological Science Covenant University Canaan Land, Ota, Ogun State, Nigeria \\ ${ }^{3}$ Department of Microbiology, Federal University of Technology, PMB 1526, Owerri, Imo State, Nigeria \\ ${ }^{4}$ Department of Applied Microbiology, Ebonyi State University, PMB 53 Abakaliki, Ebonyi State, Nigeria
}

\begin{abstract}
Effect of African breadfruit (ABF) pulp retting on the characteristics of the oil extracted from the seeds was investigated. The microbial samples identified in the retting of African breadfruit pulp were used to ret the fresh pulp. $10 \mathrm{ml}$ saline suspension of these identified microbial isolates were inoculated into the different parts of fresh ABF pulp and allowed to ret while the $\mathrm{pH}$, total titratable acidity (TTA) and temperature were monitored. The $\mathrm{pH}$ reduced from 5.4 to 5.0 in the natural retting, 5.4 to 3.8 with single microbial culture and 4.7 to 5.8 with mixed microbial culture, TTA of 0.30 to 0.86 in natural retting, 0.19 to 0.62 with single microbial culture and 0.18 to 0.60 with mixed cultures. The temperature generally ranged from 25.0 to 32.5 . The percentage oil yield increased from $1.25 \%$ to $2.76 \%$, Acid value decreased from 9.68 to 3.36 , Free fatty acid decreased from 4.87 to 1.69 , Saponification value increased from $90.69 \mathrm{mg} \mathrm{KOH} / \mathrm{g}$ to $371.66 \mathrm{mg} \mathrm{KOH} / \mathrm{g}$, Peroxide value decreased from 12.50 to 3.11 , lodine value increased from 13.98 to 59.68 , Specific gravity increased from 0.8900 to 0.9250 , Melting point from 10.0 to 22.50 and Photometric colour index increased from 0.114 to 0.319 .
\end{abstract}

Keywords: Titratable acidity; Microbial culture; Microbial isolates; Saponification

\section{Introduction}

African breadfruit (Treculia africana) is a tropical African tree crop of the Moraceae family and genus Treculia. In West Africa, individual breadfruit trees are found scattered throughout the southern rain forest zones [1]. The tree is a native of several tropical countries such as Ghana, Sierra Leone, Angola, Mozambique, Sudan, Nigeria, etc. In Nigeria it is very common in both Western and Eastern states. It is known by such names like "afon" (Yoruba), "barafuta" (Hausa) "Ize" (Benin) "eyo" (Igala) "Edikang" (Efik) and "Ukwa" (Igbo) [2]. The fruit head is spherical in shape with a diameter of up to $0.5 \mathrm{~m}$. It is hard and spongy in texture and contains spherical shaped seeds embedded at various depths in the fleshy fruit head [3]. Fermentation is done to degrade the fruit pulp and seed mucilage in order to facilitate the extraction of the seeds. The traditional fermentation process as a method of seed extraction and demucilagination imparts a characteristic offensive odour to the seeds. Besides, subsequent cleaning of the seeds after fermentation is slow, dirty and tedious requiring very large volumes of water [4]. The African breadfruit seeds are coated with gummy sticky substances which must be removed during processing [5].

African breadfruit extracted have not only being found to be highly nutritious when adequately processed, but also contain fats and oil [6]. Oil seeds (groundnut, soya bean, palm kernel, cotton seed, sunflower seed, melon seed and locust bean) are the second most valuable commonly in the world trade today [7]. Many literatures show a relatively high fat and oil content of about $13.7 \%$ in African breadfruit which yields about $9 \mathrm{kcal} / \mathrm{g}$ when oxidized in the body. This makes it to be considered as a source of oil. The oil yield of African breadfruit compares favourably with that of sunflower seed, cotton seed and palm kernel. The fat and oil content of the seed places it as a possible commercial raw material for the production of vegetables oils, pharmaceuticals, soaps, perfumes and paints [5]. However, the retting of African breadfruit may influence the characteristics of the oil extracted from the African breadfruit such as the iodine value, peroxide value, saponification value, melting point, specific gravity, acid value and free fatty acid. This study was undertaken to study the retting of African breadfruit pulp with single and mixed microbial isolates and the effect of retting on the characteristics of the oil extracted from the seeds.

\section{Methods and Materials}

Freshly fallen African breadfruits (ABF) pulp was carried from the farm at Emekuku, Owerri to the Laboratory for analysis. The African breadfruit $(\mathrm{ABF})$ was left in the laboratory to ret naturally for about 12 14 days during which the temperature and $\mathrm{pH}$ were measured.

\section{Microbiological analysis}

$10 \mathrm{~g}$ of the African breadfruit (ABF) pulp with its seeds were collected at random from the different parts of the naturally retting $\mathrm{ABF}$ and homogenized in a sterile waring blender and $1.0 \mathrm{~g}$ of the homogenate was mixed with $10 \mathrm{ml}$ of sterile saline which was serially diluted.

Isolation of microorganisms from the naturally retting African breadfruit (ABF) pulp

Nutrient agar (oxoid), De Man Rogossa Sharpe agar, Potato Dextrose agar and Malt extract agar were aseptically prepared according to the manufacturer's instructions. Nutrient agar was incubated at $30^{\circ} \mathrm{C}$ for 24-48 h and De Man Rogossa sharpe for 48-72 h, Potato Dextrose agar (PDA) and Malt Extract Agar (MEA) were incubated at $28 \pm 1^{\circ} \mathrm{C}$ for 3-5days [8-10].

*Corresponding author: Uzoh CV, Department of Microbiology, Federal University Ndufu-Alike Ikwo PMB 1010 Abakaliki Ebonyi State, Nigeria, Tel: 2348068582884; E-mail: optchuks@yahoo.com

Received September 15, 2017; Accepted November 09, 2017; Published November 16, 2017

Citation: Uzoh CV, Oranusi SU, Braide W, Orji JO, Onuoha CO (2017) Effect of Retting of African Breadfruit Pulp on the Oil Characteristics of the Seeds. J Microb Biochem Technol 9: 280-284. doi: 10.4172/1948-5948.1000378

Copyright: @ 2017 Uzoh CV, et al. This is an open-access article distributed under the terms of the Creative Commons Attribution License, which permits unrestricted use, distribution, and reproduction in any medium, provided the original author and source are credited. 


\section{Identification and characterization of isolates}

Bacterial isolates were identified and characterized on the basis of cultural, morphological, biochemical and Grams reaction. The identification scheme used were those of Cheesbrough [10] and Harrigan and McCance [11] and Domsch et al. [12].

\section{Identification of fungal isolates}

The pure isolated fungi were identified using cultural and morphological features according to the standard keys in fungal identification [13-15].

\section{Natural retting of African breadfruit (ABF)}

Fresh African breadfruit $(\mathrm{ABF})$ was brought in front of the laboratory and kept under a natural environment and allowed to ret naturally. Time/duration, $\mathrm{pH}$ and temperature were recorded during the period of retting.

\section{Retting of fresh ABF pulp with single microbial isolates}

Each surface sterilized fresh ABF pulp was opened with small circular cuts at different points on the surface using a sterile scapel blade [16]. Ten millilitres $(10 \mathrm{ml})$ of saline suspension of each pure culture isolated was inoculated into the opened surfaces of the ABF pulp and allowed to ret completely to aid seed recovery. The time, $\mathrm{pH}$ and temperature were recorded. The degree of retting and its complete retting was determined by the penetration test. When completely retted, the seed were easily separated from the pulp by severally washing with water.

\section{Mixed culture retting of African Breadfruit (ABF) Pulp}

Each surface sterilized fresh ABF pulp was opened with small circular cuts at different points on the surface using a sterile scapel blade $[16,17] .10 \mathrm{ml}$ of saline suspension of mixed isolates chosen for its previous performance in retting of African breadfruit (ABF) pulp was inoculated into the opened surfaces of ABF pulp and allowed to ret during which the degree of retting and its complete retting was assessed by pressing the pulp with sterile blunt forceps. The time, $\mathrm{pH}$ and temperature were recorded during this period of retting.

\section{Seed recovery}

African breadfruit $(\mathrm{ABF})$ seeds were recovered by manually separating the seeds from the remains of ABF retted pulp and washed several times with water in mesh or plastic basket to remove the mucilage and some other impurities.

\section{Extraction of oil}

The undehulled African breadfruit (ABF) seeds were sun dried. This ensures a separation between the outer coat and the inner content of the seeds. The seeds were dehulled with a loosely set Corona grinder (Landers CIA S.A Medellin, Colombia). The dehulled ABF seeds were ground with Corona grinder and heat-activated for about 15-20 min. This ensures that the oil molecules in the ABF seeds were activated. It was put into a mesh, and a fabricated mechanical press was used to extract the oil. The oil yield was recorded, put in a bottle and was taken to the laboratory for physicochemical analysis.

The percentage quantity of oil extracted was determined using the equation below

$$
\% \text { oil }=\frac{P}{M} \times 100
$$

Where $\mathrm{P}=$ mass of the oil,

$\mathrm{M}=$ mass of the sample used (ABF)

\section{Physicochemical properties of African breadfruit seed oil photometric colour index}

Photometric colour index (PCI) of African breadfruit seed oil was determined on $1 \mathrm{~g}$ sample according to the method described by Pike [17]. The sample was weighed and dissolved in $20 \mathrm{ml}$ water/ethanol mixture. The mixture was filtered after standing for $30 \mathrm{~min}$. The absorbance of the filtrate was measured at 400, 550, 620 and $670 \mathrm{~nm}$ using spectrophotometer. The solvent was used as blank

Photometric colour index was calculated as:

$\mathrm{PCI}=\mathrm{A} 400+\mathrm{A} 550+\mathrm{A} 620-\mathrm{A} 670$

Where, $\mathrm{A}=$ absorbance

\section{Specific gravity}

The specific gravity (SG) of the extracted oils was determined from the ratio of the mass of a specified volume of oil in pycnometer to the mass of an equal volume of water, at temperatures of $40^{\circ} \mathrm{C}$ in water bath. The empty pycnometer was weighed (mass 'a') then the pycnometer was filled with distilled water and kept at $40^{\circ} \mathrm{C}$ until it reached this temperature and then weighed (mass ' $b$ '). The same pycnometer was then filled with oil and kept in thermostated bath at $40^{\circ} \mathrm{C}$ until it reached (mass ' $c$ '). The formula used to calculate the SG was;

$$
S G=\left[\frac{c-a \times D_{O}}{b-a}\right]
$$

Where $a=$ Mass of the empty pycnometer, $b=$ Mass of the pycnometer full of water at $40^{\circ} \mathrm{C}, \mathrm{C}=$ mass of the pycnometer full of African breadfruit seed oil at $40^{\circ} \mathrm{C}$ and $\mathrm{D}_{\mathrm{o}}=$ density of water at $40^{\circ} \mathrm{C}$ $(0.9922 \mathrm{~g} / \mathrm{ml})$.

\section{Melting point}

The complete melting point ( $\mathrm{cmp}$ ) of the oils was determined using a fusiometer $[18,19]$. A melting point capillary tube was filled with oil from the open end of tube, placed in the melting point apparatus through one of the side tubes so that the sealed end of the capillary was touching the front of the mercury reservoir of the thermometer. It is heated with a micro burner and the melting point range was recorded.

\section{Iodine value}

For iodine values $0.20 \mathrm{~g}$ of oil sample was dissolved in $15 \mathrm{ml}$ carbon tetrachloride in $100 \mathrm{ml}$ glass stoppered flask. $25 \mathrm{ml}$ of Wijis solution was added; the flask stoppered and allowed to stand for $2 \mathrm{~h}$ in the dark at $25^{\circ} \mathrm{C}$ [20]. $20 \mathrm{ml}$ of $10 \%$ potassium iodine (KI) solution was added and mixture titrated with $0.2 \mathrm{~N}$ sodium thiosulphate $\left(\mathrm{Na}_{2} \mathrm{~S}_{2} \mathrm{O}_{3}\right)$ using starch indicator.

\section{Saponification value}

Saponification value of the oil samples were determined as described below:

$1 \mathrm{~g}$ of each oil extracted from African breadfruit was dissolved in $12.5 \mathrm{ml}$ of $0.5 \%$ ethanolic $\mathrm{KOH}$ and the mixture refluxed for $30 \mathrm{~min} .1$ $\mathrm{ml}$ of phenolphthalein indicator was added and the hot soap solution titrated with $0.5 \mathrm{~N}$ HCL.

Saponification value $=\frac{56.1 \mathrm{~N}\left(V_{1}-V_{2}\right)}{W}$

Where, $\mathrm{N}=$ Normality of hydrochloric acid used 
Citation: Uzoh CV, Oranusi SU, Braide W, Orji JO, Onuoha CO (2017) Effect of Retting of African Breadfruit Pulp on the Oil Characteristics of the Seeds. J Microb Biochem Technol 9: 280-284. doi: 10.4172/1948-5948.1000378

V1=Volume of hydrochloric acid used in test

V2=Volume of hydrochloric acid used in blank

W=Weight of oil used $(1 \mathrm{~g})$

\section{Peroxide value (PV)}

$1 \mathrm{~g}$ of each oil sample was weighed into a $200 \mathrm{ml}$ conical flask then $25 \mathrm{ml}$ of $2: 1 \mathrm{v} / \mathrm{v}$ glacial acetic chloroform solvent was added $1 \mathrm{ml}$ of saturated potassium iodine was then added and mixture left in the dark for $1 \mathrm{~min}$.

Next, $30 \mathrm{ml}$ of water was added and the mixture titrated with 0.02 $\mathrm{N}$ thiosulphate solution using $5 \mathrm{ml}$ starch as indicator.

A blank determination was similarly carried out. PV was calculated from the equation.

Peroxide value $(P V)=\frac{\left(100\left(V_{1}-V_{2}\right) m e g / \mathrm{kg}\right)}{W}$

$\mathrm{W}=$ Weight of sample

$\mathrm{V} 1=$ Volume $(\mathrm{ml})$ of thiosulphate used in test

$\mathrm{V} 2=$ Volume $(\mathrm{ml})$ of thiosulphate used in blank

$\mathrm{N}=$ Normality of thiosulphate $\left(\mathrm{Na}_{2} \mathrm{~S}_{2} \mathrm{O}_{3}\right)$

\section{Acid value}

The acid value was determined for each oil sample by dissolving $0.20 \mathrm{~g}$ of each oil in $2.5 \mathrm{ml}$ of $1: 1 \mathrm{v} / \mathrm{v}$ ethanol: diethylether solvent and titrating with $0.1 \mathrm{~N}$ sodium hydroxide while swirling using phenolphthalein as indicator (Tables 1-9).

\begin{tabular}{|l|c|c|c|c|}
\hline \multicolumn{1}{|c|}{ Test } & \multicolumn{1}{|c|}{ Isolates } & B & C1 & A2 \\
\hline & $\begin{array}{c}\text { Yellow cocci } \\
\text { with raised } \\
\text { entire colonies }\end{array}$ & $\begin{array}{c}\text { Rods in chains, } \\
\text { slender colonies }\end{array}$ & $\begin{array}{c}\text { Cocci in chains, } \\
\text { tiny colonies }\end{array}$ & $\begin{array}{c}\text { Whitish, } \\
\text { raised } \\
\text { rods. }\end{array}$ \\
\hline Grams reaction & - & + & + & + \\
\hline Spore staining & - & - & - & + \\
\hline Capsule staining & - & - & - & - \\
\hline Motility & - & - & - & + \\
\hline Oxidase test & + & - & - & - \\
\hline Catalase test & + & - & - & - \\
\hline Citrate utilization & + & - & - & - \\
\hline Glucose & + & + & - & + \\
\hline Gas & - & - & + & - \\
\hline Urease & - & - & - & - \\
\hline Coagulase & - & - & - & - \\
\hline Indole & - & - & - & - \\
\hline Methyl red & - & - & - & - \\
\hline Organism & Micrococcus sp. & Lactobacillus sp. & Streptococcus sp. & Bacillus sp. \\
\hline
\end{tabular}

+ positive reaction, - negative reaction

Table 1: The bacterial isolates identified were designated A1, B, C1 and A2. Mixed flora of bacteria were found to be responsible for the retting of the African breadfruit pulp.

\begin{tabular}{|c|c|c|}
\hline Colonial characteristics & $\begin{array}{l}\text { Microscopic Isolates } \\
\text { Code Appearance }\end{array}$ & Organism identified \\
\hline $\begin{array}{l}\text { Tall White filamentous } \\
\text { hyphae }\end{array}$ & non-septate hyphae $X$ & Rhizopus stolonifer \\
\hline $\begin{array}{l}\text { Black spores on short white } \\
\text { hyphae }\end{array}$ & $\begin{array}{c}\text { hyphae septate conidia } \\
\text { sterigma } Y\end{array}$ & Aspergillus niger \\
\hline
\end{tabular}

Table 2: Characterization and identification of fungal isolates.

\begin{tabular}{|c|c|}
\hline Characteristics & Isolates \\
\hline Surface & Smooth \\
\hline Margin & Circular \\
\hline Colour & Creamy white \\
\hline Cells & spherical/oval \\
\hline Gram stain reaction & + \\
\hline Glucose & + \\
\hline Catalase & + \\
\hline Galactose & + \\
\hline Maltose & + \\
\hline Sucrose & + \\
\hline Lactose & + \\
\hline Growth at $25^{\circ} \mathrm{C}$ & + \\
\hline Growth at $30^{\circ} \mathrm{C}$ & Saccharomyces cerevisiae \\
\hline Isolate identified & \\
\hline
\end{tabular}

-: Negative result (no acid production) +: Positive result (acid produced)

Table 3: Morphological, cultural and biochemical characteristics of yeast strain isolated.

\begin{tabular}{|c|c|c|}
\hline $\begin{array}{l}\text { Fermentation } \\
\text { period (days) }\end{array}$ & $\begin{array}{l}\text { Total count } \\
\text { (cfu/g) }\end{array}$ & Predominant flora \\
\hline 0 & $10^{2}$ & $\begin{array}{l}\text { Mixed populations of Micrococcus and } \\
\text { Streptococcus species. }\end{array}$ \\
\hline 2 & $2.4 \times 10^{2}$ & Micrococcus sp., Streptococcus sp., Bacillus sp. \\
\hline 4 & $2.3 \times 10^{4}$ & Lactobacillus sp., Bacillus subtilis \\
\hline 6 & $1.6 \times 10^{6}$ & Lactobacillus sp., Bacillus subtilis \\
\hline 8 & $3.0 \times 10^{9}$ & Lactobacillus sp., Bacillus subtilis \\
\hline 10 & $3.5 \times 10^{10}$ & Lactobacillus sp., Bacillus subtilis \\
\hline 12 & $2.8 \times 10^{8}$ & Lactobacillus sp., Bacillus subtilis \\
\hline 14 & $1.8 \times 10^{3}$ & Lactobacillus sp., Bacillus subtilis \\
\hline
\end{tabular}

Table 4: Microbial counts and composition of bacteria during natural retting of African breadfruit pulp.

\begin{tabular}{|c|c|c|c|c|c|c|c|c|}
\hline Isolates & $\mathbf{p H}_{\text {Day0 }}$ & $\mathbf{p H}_{\text {Day2 }}$ & $\mathbf{p H}_{\text {Day4 }}$ & $\mathbf{p H}_{\text {Day6 }}$ & $\mathbf{p H}_{\text {Day8 }}$ & $\mathbf{p H}_{\text {Day10 }}$ & $\mathbf{p H}_{\text {Day12 }}$ & $\mathbf{p H}_{\text {Day14 }}$ \\
\hline $\mathrm{NR}$ & 5.4 & 5.4 & 5.3 & 5.3 & 5.2 & 5.1 & 5.1 & 5.0 \\
\hline $\mathrm{C} 1$ & 5.4 & 5.9 & 5.3 & 5.2 & 5.2 & 5.2 & 5.2 & 5.2 \\
\hline $\mathrm{Z}$ & 5.4 & 5.4 & 5.3 & 5.1 & 5.0 & 5.0 & 5.0 & 5.0 \\
\hline $\mathrm{A} 2$ & 5.4 & 5.2 & 5.0 & 4.9 & 4.8 & 4.8 & 4.8 & 4.8 \\
\hline $\mathrm{Y}$ & 5.4 & 5.3 & 5.2 & 5.0 & 4.8 & 4.8 & 4.8 & 4.8 \\
\hline $\mathrm{B}$ & 5.4 & 5.1 & 4.5 & 4.2 & 3.8 & 3.8 & 3.8 & 3.8 \\
\hline $\mathrm{X}$ & 5.4 & 5.4 & 5.3 & 5.2 & 5.1 & 5.1 & 5.1 & 5.1 \\
\hline $\mathrm{A}_{1}$ & 5.4 & 5.8 & 5.2 & 5.0 & 4.9 & 4.9 & 4.9 & 4.9 \\
\hline $\mathrm{A}_{2} \mathrm{Z}$ & 5.4 & 5.2 & 5.0 & 4.9 & 4.7 & 4.7 & 4.7 & 4.7 \\
\hline $\mathrm{C}_{1} \mathrm{Z}$ & 5.4 & 5.3 & 5.1 & 5.0 & 4.9 & 4.9 & 4.9 & 4.9 \\
\hline $\mathrm{BZ}$ & 5.4 & 5.2 & 5.0 & 4.7 & 4.5 & 4.6 & 4.6 & 4.6 \\
\hline
\end{tabular}

Table 5: pH fluctuation of the different retting pulp.

NR: Natural Retting; C1: Streptococcus sp.; Z: Saccharomyces cerevisiae; A2 Bacillus sp.; Y: Aspergillus niger; B: Lactobacillus sp.; X: Rhizopus stolonifer; A1: Micrococcus sp.; A Z: Bacillus sp./Saccharomyces cerevisiae; $\mathrm{C}_{1} \mathrm{Z}$ : Streptococcus sp./Saccharomyces cerevisiae; BZ: Lactobacillus sp./Saccharomyces cerevisiae

The Predominant bacteria are presented in Table 5. Micrococcus sp. and Streptococcus sp. were initially present within the first 2 days after which Lactobacillus sp. and Bacillus sp. dominated until the pulp was completely retted.

\section{Results}

The microorganisms that were associated with the retting of $\mathrm{ABF}$ pulp were isolated and identified as Micrococcus sp., Lactobacillus sp., Streptococcus sp., Bacillus subtilis, Aspergillus niger, Rhizopus stolonifer and Saccharomyces cerevisiae. The ability of the isolates to hydrolyze 


\begin{tabular}{|c|c|c|c|c|c|c|c|c|}
\hline Isolates & $\mathbf{T T A}_{\text {Day0 }}$ & $\mathbf{T T A}_{\text {Day2 }}$ & $\mathbf{T T A}_{\text {Day4 }}$ & $\mathbf{T T A}_{\text {Day6 }}$ & $\mathbf{T T A}_{\text {Day8 }}$ & $\mathbf{T T A}_{\text {Day10 }}$ & $\mathbf{T T A}_{\text {Day12 }}$ & $\mathbf{T T A}_{\text {Day14 }}$ \\
\hline $\mathrm{NR}$ & 0.30 & 0.36 & 0.85 & 0.86 & 0.72 & 0.65 & 0.60 & 0.52 \\
\hline $\mathrm{C}_{1}$ & 0.19 & 0.21 & 0.22 & 0.24 & 0.26 & 0.26 & 0.26 & 0.26 \\
\hline $\mathrm{Z}$ & 0.20 & 0.22 & 0.24 & 0.25 & 0.26 & 0.26 & 0.26 & 0.26 \\
\hline $\mathrm{A}_{2}$ & 0.20 & 0.24 & 0.27 & 0.30 & 0.32 & 0.32 & 0.32 & 0.32 \\
\hline $\mathrm{Y}$ & 0.19 & 0.21 & 0.23 & 0.24 & 0.25 & 0.25 & 0.25 & 0.25 \\
\hline $\mathrm{B}$ & 0.22 & 0.32 & 0.46 & 0.48 & 0.62 & 0.62 & 0.62 & 0.62 \\
\hline $\mathrm{X}$ & 0.22 & 0.23 & 0.23 & 0.25 & 0.26 & 0.26 & 0.26 & 0.26 \\
\hline $\mathrm{A}_{1}$ & 0.18 & 0.19 & 0.20 & 0.22 & 0.22 & 0.22 & 0.22 & 0.22 \\
\hline $\mathrm{A}_{2} \mathrm{Z}$ & 0.27 & 0.30 & 0.35 & 0.48 & 0.50 & 0.50 & 0.50 & 0.50 \\
\hline $\mathrm{C}_{1} \mathrm{Z}$ & 0.20 & 0.19 & 0.25 & 0.30 & 0.34 & 0.34 & 0.34 & 0.34 \\
\hline $\mathrm{BZ}$ & 0.29 & 0.35 & 0.45 & 0.51 & 0.60 & 0.61 & 0.60 & 0.60 \\
\hline
\end{tabular}

Table 6: Total titratable acidity (TTA) of the different ABF retted with different microbial isolates.

\begin{tabular}{|c|c|c|c|c|c|c|c|c|}
\hline Isolates & $\mathbf{T}_{\text {Day0 }}$ & $\mathbf{T}_{\text {Day2 }}$ & $\mathbf{T}_{\text {Day4 }}$ & $\mathbf{T}_{\text {Day6 } 6}$ & $\mathbf{T}_{\text {Day8 }}$ & $\mathbf{T}_{\text {Day10 }}$ & $\mathbf{T}_{\text {Day12 }}$ & $\mathbf{T}_{\text {Day14 }}$ \\
\hline $\mathrm{NR}$ & 27 & 27.5 & 28 & 30 & 29 & 27.5 & 27 & 27 \\
\hline $\mathrm{C}_{1}$ & 30 & 30 & 31 & 31 & 28 & 28 & 25 & 25 \\
\hline $\mathrm{Z}$ & 29 & 30 & 31 & 28.5 & 27 & 27 & 26 & 25 \\
\hline $\mathrm{A}_{2}$ & 29 & 29.5 & 30 & 31 & 29 & 29 & 28 & 28 \\
\hline $\mathrm{Y}$ & 30 & 31 & 27 & 29 & 29 & 29 & 27 & 27 \\
\hline $\mathrm{B}$ & 28 & 29.5 & 30.5 & 32 & 27 & 27 & 26 & 25 \\
\hline $\mathrm{X}$ & 30 & 30 & 29.5 & 31 & 30 & 30 & 28 & 28 \\
\hline $\mathrm{A}_{1}$ & 30 & 30.5 & 31 & 30 & 29 & 29 & 28 & 26 \\
\hline $\mathrm{A}_{2} \mathrm{Z}$ & 30 & 31.5 & 32.5 & 31 & 29 & 28 & 27 & 25.5 \\
\hline $\mathrm{C}_{1} \mathrm{Z}$ & 29 & 28 & 29 & 30 & 27.5 & 26.5 & 26 & 25 \\
\hline $\mathrm{BZ}$ & 29 & 29.5 & 31 & 32 & 28.5 & 28 & 27 & 25 \\
\hline
\end{tabular}

Table 7: Temperature fluctuations of different isolates during the retting of the African breadfruit pulp.

\begin{tabular}{|c|c|}
\hline Isolates & Percentage yield \\
\hline $\mathrm{NR}$ & 1.25 \\
\hline $\mathrm{C}_{1}$ & 1.80 \\
\hline $\mathrm{Z}$ & 1.88 \\
\hline $\mathrm{A}_{2}$ & 2.19 \\
\hline $\mathrm{Y}$ & 1.85 \\
\hline $\mathrm{B}$ & 2.08 \\
\hline $\mathrm{X}$ & 1.67 \\
\hline $\mathrm{A}_{1}$ & 1.53 \\
\hline $\mathrm{A}_{2} \mathrm{Z}$ & 2.76 \\
\hline $\mathrm{C}_{1} \mathrm{Z}$ & 2.33 \\
\hline $\mathrm{BZ}$ & 2.50 \\
\hline
\end{tabular}

Table 8: Percentage of oil yield from the seeds of the different microbially retted pulp. starch indicates that they may possess active extracellular amylolytic enzymes which are likely to convert starch into fermentable sugars which are the main substrates for the lactic acid bacteria [21]. From Table 5, it was observed that the $\mathrm{pH}$ lasted up to the day 14, while that of single/pure microbial cultures $\left(\mathrm{A}_{1}, \mathrm{~B}, \mathrm{C}_{1}, \mathrm{~A}_{2}, \mathrm{X}, \mathrm{Y}, \mathrm{Z}\right)$ lasted up to day 10 and that of mixed microbial cultures (BZ, $C_{1} Z, A_{2} Z$ ) lasted for 8 days only. This confirms efficient and improved retting of ABF pulp with mixed microbial cultures. From the illustration above, mixed microbial culture retting is greater than pure/single microbial culture retting and this is greater than natural retting. The natural retting of $\mathrm{ABF}$ pulp for seed recovery is the most prolonged in terms of the time for the retting process to be completed. This was as a result of undesirable microorganisms present in the pulp Natural fermentation by adventitious bacteria present in the raw materials (ABF pulp) involves undesirable microorganisms, which results in delayed pulp tissue disintegration [17]. The percentage of oil from the seeds of the African breadfruit $(\mathrm{ABF})$ that was retted by the microbial isolates (single/pure culture and mixed cultures) as shown in Table 9. The total percentage of oil content of the ABF pulp retted by the different microbial isolates ranged from $1.25 \%-2.76 \%$. A2Z retted ABF had the highest oil seed content (2.76\%) followed by BZ (2.50\%) and $\mathrm{C}_{1} \mathrm{Z}$ $(2.33 \%)$ while that of natural retting (NR) had the lowest oil content of $1.25 \%$. Most popular plant seed oils have specific gravity ranging from 0.9100 to 0.9400 and specific gravity of 0.92 is considered a pretty good number for any cooking oil [22]. Some authors have stated that the specific gravity suitable for edible oils range from 0.8800 to 0.9400 [23]

\section{Discussion}

From the above values, it was observed that the faster the retting process, the less the value of the specific gravity (SG). The values obtained compares with that reported for palm oil (0.91) and groundnut (0.84) [24]. All these melting point values are suitable for cooking and as edible oils $\left(-20^{\circ} \mathrm{C}\right.$ to $\left.44^{\circ} \mathrm{C}\right)$ [25]. From the melting point values of the $\mathrm{ABF}$ seeds, it was obvious that the faster the retting process, the less the melting point. This implies that the more the retting process is prolonged, the higher the melting point. The photometric colour index varied from 0.114 to 0.319 . Unlike the melting points above, the photometric colour index (PCI) did not follow any particular trend or order with respect to the duration of the retting process. The NR is the one with the lowest photometric colour index (Table 9). BZ (0.319) showed the highest value of PCI which was followed by that of C1Z (i.e., one out of the three mixed microbial cultures used for the retting process). These confirm that PCI values do not follow a particular sequence or order as the time/

\begin{tabular}{|c|c|c|c|c|c|c|c|c|c|}
\hline Isolates & $\begin{array}{l}\text { Acid value (mg } \\
\mathrm{KOH} / \mathrm{g})\end{array}$ & $\begin{array}{l}\text { Free fatty acid } \\
\text { (\%FFA) }\end{array}$ & $\begin{array}{l}\text { Saponification } \\
\text { value }(\mathrm{mg} \mathrm{KOH} / \mathrm{g})\end{array}$ & Peroxide value & lodine value & Specific gravity & $\begin{array}{l}\text { Melting point } \\
\left({ }^{\circ} \mathrm{C}\right)\end{array}$ & $\begin{array}{l}\text { Photometric } \\
\text { colour index }\end{array}$ & $\begin{array}{l}\text { Oil } \\
\text { content }\end{array}$ \\
\hline NR & $9.68 \pm 0.008$ & $4.87 \pm 0.018$ & $90.69 \pm 0.122$ & $12.50 \pm 0.700$ & $41.49 \pm 0.826$ & $0.9133 \pm 0.041$ & $15.5 \pm 0.500$ & $0.114 \pm 0.114$ & 1.25 \\
\hline $\mathrm{C}_{1}$ & $6.77 \pm 0.009$ & $3.40 \pm 0.005$ & $64.73 \pm 0.043$ & $4.80 \pm 0.300$ & $49.53 \pm 0.756$ & $0.8933 \pm 0.064$ & $19.5 \pm 0.500$ & $0.262 \pm 0.131$ & 1.80 \\
\hline$Z$ & $5.10 \pm 0.200$ & $2.56 \pm 0.069$ & $151.15 \pm 0.018$ & $10.94 \pm 0.683$ & $32.49 \pm 1.772$ & $0.9000 \pm 0.052$ & $12.0 \pm 2.000$ & $0.148 \pm 0.004$ & 1.88 \\
\hline$A_{2}$ & $4.00 \pm 0.031$ & $2.01 \pm 0.005$ & $132.23 \pm 0.250$ & $9.60 \pm 1.160$ & $46.64 \pm 0.210$ & $0.9033 \pm 0.008$ & $17.0 \pm 1.000$ & $0.138 \pm 0.021$ & 2.19 \\
\hline $\mathrm{Y}$ & $6.23 \pm 0.012$ & $3.13 \pm 0.013$ & $130.90 \pm 1.300$ & $3.52 \pm 0.330$ & $22.90 \pm 0.202$ & $0.8950 \pm 0.005$ & $22.5 \pm 1.500$ & $0.162 \pm 0.162$ & 1.85 \\
\hline$B$ & $4.48 \pm 0.008$ & $2.25 \pm 0.017$ & $123.67 \pm 1.050$ & $4.40 \pm 0.565$ & $55.70 \pm 2.285$ & $0.9025 \pm 0.054$ & $14.5 \pm 0.500$ & $0.155 \pm 0.155$ & 2.08 \\
\hline$x$ & $7.65 \pm 0.006$ & $3.84 \pm 0.067$ & $182.32 \pm 3.075$ & $3.46 \pm 0.354$ & $45.40 \pm 0.700$ & $0.9200 \pm 0.013$ & $14.5 \pm 1.500$ & $0.131 \pm 0.131$ & 1.67 \\
\hline$A_{1}$ & $8.54 \pm 0.115$ & $4.27 \pm 0.05$ & $202.46 \pm 1.061$ & $4.20 \pm 0.914$ & $43.20 \pm 0.300$ & $0.9156 \pm 0.059$ & $17.5 \pm 0.500$ & $0.167 \pm 0.167$ & 1.53 \\
\hline$A_{2} Z$ & $3.36 \pm 0.004$ & $1.69 \pm 0.010$ & $371.66 \pm 0.393$ & $3.11 \pm 0.789$ & $13.98 \pm 0.281$ & $0.8900 \pm 0.569$ & $10.0 \pm 3.000$ & $0.216 \pm 0.001$ & 2.76 \\
\hline$C_{1} Z$ & $4.00 \pm 0.002$ & $2.01 \pm 0.014$ & $232.19 \pm 0.012$ & $5.50 \pm 0.150$ & $58.43 \pm 0.830$ & $0.9033 \pm 0.058$ & $14.0 \pm 2.000$ & $0.285 \pm 0.001$ & 2.33 \\
\hline$B Z$ & $3.65 \pm 0.002$ & $1.83 \pm 0.009$ & $254.20 \pm 0.011$ & $5.27 \pm 0.248$ & $59.68 \pm 0.550$ & $0.9250 \pm 0.015$ & $10.5 \pm 0.500$ & $0.319 \pm 0.002$ & 1.25 \\
\hline
\end{tabular}

Table 9: The physicochemical properties of the oil extracted from ABF seeds.

NR: Natural Retting; C1: Streptococcus sp.; Z: Saccharomyces cerevisiae; A2: Bacillus sp.; Y: Aspergillus niger, B: Lactobacillus sp.; X: Rhizopus stolonifer, A1: Micrococcus sp.; A Z: Bacillus sp./Saccharomyces cerevisiae; C Z: Streptococcus sp./Saccharomyces cerevisiae; BZ: Lactobacillus sp./Saccharomyces cerevisiae 
Citation: Uzoh CV, Oranusi SU, Braide W, Orji JO, Onuoha CO (2017) Effect of Retting of African Breadfruit Pulp on the Oil Characteristics of the Seeds. J Microb Biochem Technol 9: 280-284. doi: 10.4172/1948-5948.1000378

duration of the retting process progresses or retrogresses. The acid value $(\mathrm{AV})$ is least for $\mathrm{A}_{2} \mathrm{Z}$ (3.366) and NR was the highest with a value of 9.688. In addition, all the values fall in within an acceptable range of 0.00 to $10.00 \mathrm{mg} \mathrm{KOH} / \mathrm{g}$. The oils intended for human dietary purpose should not contain high free fatty acid. Edible oils such as palm oil have been reported to contain an average of 19.3 acid values [25]. It became imperative that as the rate of retting of the $\mathrm{ABF}$ decreases, the acid value increases. This indicates that the mixed microbial cultures that were used to bring about retting at a faster period of time gave a reasonably low acid value which augurs well with its use as edible/cooking oil. The FFA of the ABF oil extracted ranged from 1.692 to 4.875 with These values were within the maximum limit of $<5 \%$ as seen in the FFA value of high grade palm oil in Nigeria [26,27]. The maximum FFA value was 4.875 and analyzing the values showed that as the rate of retting became faster (i.e., less duration of complete retting), the less the FFA value (i.e., the FFA decreases). The FFA and acid value of the oils extracted from $\mathrm{ABF}$ are low which indicates that they probably could be stored for a long time without spoilage through oxidative rancidity and will find application as edible/cooking oils $[28,29]$. The saponification values were high although most of these values were comparable to 146.44 \pm 4.76 from the ABF seed oil extracted by Ajiwe et al. $[27,28]$ for the saponification values of physic nut and Nicker nut as $112 \pm 0.20$ and $197.12 \pm 0.08$, respectively [30-33].

\section{Conclusion}

In conclusion, the results of this work shows that the pure and mixed microbial cultures used retted the ABF pulp faster thereby enhancing the fast recovery of the seeds. The different oils (African breadfruit oil- ABFO) extracted from the seeds showed that the yield of oil from these seeds varied according to the duration of the retting of the ABF pulp as those mixed microbial cultures which retted $A B F$ pulp faster (e.g. $\mathrm{BZ}, \mathrm{A}_{2} \mathrm{Z}$ and $\mathrm{C}_{1} \mathrm{Z}$ ) gave higher yield of oil followed by the single cultures used. Generally, all the oils extracted showed physiochemical properties which make them suitable as good edible/cooking oils.

\section{References}

1. Omobuwajo TO, Akande EA, Sanni LA (1999) Selected physical, mechanical and aerodynamic properties of African breadfruit (Treculia africana) seeds. Food Eng 40: 241-244.

2. Irvine FR (1961) Woody plants of Ghana with special reference to their uses. Oxford University Press, London, pp: 112-349.

3. Enibe SO (2001) Design, Construction and testing of a breadfruit depulping machine, Landwards, Summer, pp: 16-21.

4. Onweluzo LJC, Odume L (2007) Method of extraction and demucilagination of Treculia africana: Effect on composition. Nig Food J 25: 90-95.

5. Etoamaihe UJ, Ndubueze KC (2010) Development and performance evaluation of a dehulling machine for African breadfruit (Treculia africana). J Eng Appl Sci 5: 312-315.

6. Harrigan WF, McCance ME (1998) Laboratory methods in food and dairy microbiology. Academic press, London, pp: 284-297.

7. Ige MN, Ogunsua AO, Okon OL (1984) Functional properties of the protein of some Nigerian oil seeds. Casophor seeds and three varieties of some Nigerian oil seeds. Food Chem 23: 822-825.

8. Mclandsborough L (2005) Food Microbiology Laboratory. Boca Raton: CRC press, pp: 33-90.

9. Samson RA, Varga $J(2007)$ Aspergillus systematic in the genomic era CBS fungal biodiversity centre, utretch, pp: 206-208
10. Cheesbrough M (1984) Medical laboratory manual for tropical countries. Pas worth Heinemann Itd. Britain 6: 35-69.

11. Harrigan WF, Mc Cance ME (1976) Laboratory methods in food and dairy microbiology. Academic Press Inc. London.

12. Domsch KH, Gams W, Anderson TH (1993) Compedium of soil fungi. Academic Press, London, pp: 860-865.

13. Klich MA (2002) Identification of common Aspergillus species. CBS, Utretch The Netherland.

14. Oyeleke A, Manga SB (2008) Essential of laboratory practice, $3^{\text {rd }}$ Edition, Tobest Publishers, Minna, Niger State, Nigeria, pp: 12-29.

15. Obeta JAN, Abriba C (1994) Microbiology of controlled rotting of egusi (Colocynthis citrullus L.) fruits for the harvesting of the seeds. World J Microbio Biotechnol 10: 634-636.

16. Offonry SU, Achi OK (1998) Microbial populations associated with the retting of melon pods (Colocynthis citrullus $\mathrm{L}$ ) during seed recovery. Plant Foods Hum Nutr 52: $37-47$.

17. Pike OA (2003) Fat characterization. In: Food analysis $3^{\text {rd }}$ edition. Aluwer Academic/Planum Publishers New York, pp: 227-235.

18. Baur FJ (1995) Analytical methods for oils and fats. In: Lawson, H. (ed): Food oils and fats technology, utilization and nutrition. Chapman and Hall. An International Thomson publishing company, New York, pp: 281-309.

19. AOAC (1984) Association of official analytical chemists. Official Method of Analysis $\left(14^{\text {th }}\right.$ ed). Washington D.C USA, pp: 141-142.

20. Daeschel MA, Anderson RE, Fleming HP (1987) Microbial ecology of fermenting plant materials. FEMS Microbiol Rev 46: 357-367.

21. Elert G (2000) Density of cooking oil. In: The physics factbook.

22. Toolbox (2005) Specific gravities for some common fluids and liquids as acetone, alcohol, turpentine, oil.

23. Ebuehi OAT, Umeh RA, Oletuf U (2006) Physicochemical and fatty acid composition of two common edible vegetable oils in Nigeria. Nig Food J 24: 17-24.

24. Nkafamiya II, Maina HM, Osemeahon SA, Modibbo UU (2010) Percentage oil yield and physiochemical properties of different groundnut species (Arachis hypogea). African J Food Sci 4:418-425.

25. NIFOR (2009) Nigeria institute for oil research. History, activities and achievements. 2nd Edition, Benin City 12: 26-29.

26. Oderinde RA, Ajayi IA, Adewuyi A (2009) Characterization of seed And seeds oil of Hura crepitans and the kinetics of degradation of the oil during heating Electron J Environ Agric Food Chem 8: 21-208.

27. Ajiwe VIE, Okeke CA, Agbo HU (1995) Extraction and evaluation of breadfruit seed oil (Treculia africana). Bioresource technol 53: 1183-1184.

28. Ajiwe VIE, Okeke CA, Agbo HU, Ogunleye GA, Ekwuozor SC (1996) Extraction, characterization and industrial uses of velvet-tamarind, physic-nut and nickernut seed oils. Bioresour Technol 57: 297-299.

29. Alabi DA (1993) Parkia biglobosa, an endangered species. Internationa Conference proceedings on lost crops and Trees in Africa 3: 262-285.

30. Ikhuoria EU, Aiwonegbe AE, Okoli P, Idu M (2008) Characteristics and composition of African oil bean seed (Pentaclethra macrophylla Benth). J Appl Sci 8: 1337-1339.

31. Isu NR, Njoku HO (1997) An evaluation of the microflora associated with fermented African oil Bean (Pentaclethra macrophylla) seeds during ugba production. Plant Foods Hum Nutr 51:145-157.

32. Njoku HO, Ogbulie JN, Nnubia (1990) Microbial ecology of traditiona fermentation of African oil bean seed for Ugba production. J Food Microbial 3: 18-28.

33. Nwabueze TU, Okocha KS (2008) Extraction performance of polar and nonpolar solvents on the physical and chemical indices of African breadfruit (Treculia africana) seed oil. Afr J Food Sci 2:119-125.

Citation: Uzoh CV, Oranusi SU, Braide W, Orji JO, Onuoha CO (2017) Effect of Retting of African Breadfruit Pulp on the Oil Characteristics of the Seeds. $J$ Microb Biochem Technol 9: 280-284. doi: 10.4172/1948-5948.1000378 